\title{
THE INNOVATIVE ACTIVITY IN THE BALANCED REGIONAL AND ORGANIZATIONAL DEVELOPMENT OF POLAND AND THE EUROPEAN UNION
}

\author{
SYLWIA ĆMIEL ${ }^{1}$
}

\author{
The Alcide De Gasperi University of Euroregional Economy in Jozefow (Poland)
}

\begin{abstract}
The aim of the article is the analysis of the innovative activity in the balanced development of regions and organizations in Poland and the EU. A state is responsible for the level of innovativeness transferring finances for the research and development as well as implementing proper financial and legal instruments stimulating innovative endeavours of enterprises according to the applied economy politics. An enterprise is the basic objective of the innovative politics in Poland and the EU as well as implementing innovativeness with the benefits for economy. Enterprises, especially the smaller and medium ones, try to cooperate within innovativeness with the companies from the same branches, other branches in the country and abroad, with universities, $\mathrm{B}+\mathrm{R}$ institutions, including laboratories, intermediary companies in a transfer, financing innovativeness, with scientific and technical parks, local authorities representatives as well as other representatives of an innovative environment. Those include also advisor companies, organizers of fairs, exhibitions, conferences, seminars and trainings. In Poland, the finances of innovativeness is done mainly by the companies themselves and the development of intermediary companies within transferring the EU's funds as well as the financial or credit ones that are the suppliers of the capital, e.g. venture capital.

KEYWORD: innovations, management, knowledge-based economy.
\end{abstract}

JEL CODES: O310

\section{Introduction}

The dynamics of growth on the markets resulting from the competitiveness and fast technical advance forces organizations to active participation in obtaining, creating of knowledge and using it in innovativeness. Knowledge and qualifications of organizations (including their staff) as well as innovativeness that are the result of implementing and developing them, nowadays become the source of long-term competitive prevail on the markets and the indicator of economical profit in conditions of globalization and built economy based on knowledge. Innovativeness being one of the key issue of the strategy Europe 2020, will demand making numerous more effective actions than so far within the area in the EU's member states. The postulated model of the civilization development of Poland based on the polarization-diffusion concept, as the Report of Poland 2030 claims, as well as demands of the above mentioned new strategy, should result in suitable steps to improvement of the level of innovativeness not only in industry but also in the sector of services whose importance will still grow. It is significant to create a proper system of enhancing to undertake $\mathrm{B}+\mathrm{R}$ activity and a knowledge instrument as well as recognizing existing barriers of innovative activity and effective prevention of them.

Sylwia Ćmiel - The Alcide De Gasperi University of Europregional Economy in Jozefow. Scientific interests: Innovations, Management, Human Resource, Pedagogy, Juvenile Crime, Cyber-Violence.

E-mail: sylwia@wege.edu.pl,

Tel.: +(48) 227891903 wew.13. 
The aim of the article is the analysis of the innovative activity in the balanced development of regions and organizations in Poland and the EU. In order to achieve the goal in the article, the following problems have been presented and described:

- The innovative process and innovativeness of organizations;

- Innovative activity of the sector of services in Poland and the EU;

- The process of innovation and regional development.

The method - the analysis of scientific articles, own observation.

\section{The innovative process and innovativeness of organizations}

Innovations are related with positive changes leading to facilitating the productive processes. Innovations are the function of human opportunities, logical thinking and drawing conclusions concerning new conditions and relations.

The notion of innovativeness was introduced to the sciences of economy by an Austrian economist J. A. Schumpeter at the beginning of the $20^{\text {th }}$ century. In the broaden meaning of the notion of innovativeness, the following definitions can be set as examples:

- implementing new products, technology or way of behavior to wider usage;

- everything percept by humans as a new one, independently of objective novelty of ideas or things;

- all goods percept as a new one;

- an idea, practice or object that is percept as a new one by a human or an accepting unit (Matusiak, 2010: 20-21).

The range of innovativeness of enterprises results from the character and kind of activity. The object of innovativeness may be production, technology of production, methods and instruments of work organization and processes. Scientific literature explains that an innovative enterprise is the one that substitutes the current solutions with other ones. For the statistics needs, it is accepted that an innovative enterprise means the company that has introduced a new or significantly improved product to the market or implemented new or significant processes, bought new technology, undertaken new investments and conducted trainings concerning innovativeness in the researched time, most often three year time.

Contemporary innovativeness is not limited only to technological solutions. It is important to implement new or significantly improved products, new solutions according to production, service and marketing process and organization of work (Lis, Szot-Gawryś, 2010: 6, 331).

Innovativeness means the clue of the process concerning renewing of what an organization offers (its products and/or services) as well as the ways of generating and delivering them (Pavitt et., 1998: 14). Therefore, authors distinguish three kinds of innovativeness: product (new products); process (new processes) and service (new services). Of course, not all novelties mean innovativeness. Therefore, it is worth to remind that not long ago the literature of the subject first of all the product and process innovations were distinguished, that were treated as technological advance. Distinguishing the third category of service innovation is reasonable for at least two reasons:

- services are of more and more importance in contemporary market economy;

- new services are often the result of technical advance.

In the division there is a distinction of organizational innovativeness, namely changes of corporate or work organization. Organizational innovations often accompany technical innovations, e.g. a completely new organization of the production department changing into completely new technology of manufacturing. This is a significant kind of innovation nowadays (Jasiński, 2009: 10).

Innovation is a result of complex set of processes which create together an innovative process. According to the definition of W. Janosz, the innovative process is completed in the term from the first concept to the 
first accomplishment (...) in this notion, the innovative process means material and non-material changes of elements in particular economic unit.

Implementing a new product or solution in a social practice becomes a basic event in such comprehended process (Janasz, 1999: 71). A new service may be certainly that product. The innovation is claimed to be a successful process when it consists of the following phases (Jasiński, 2009: 14):

- scanning the environment (internal and external) - for identification of market and other signals;

- strategic option choice (alternative) - in order to react on identified signals;

- allocation of funds allowing to answer the signals;

- project implementation from the concept to introduction to the market (a new product/service) or inside a company (a new manufacturing process) - in order to effective response to the signals;

- learning on the experience which is supposed to lead to advance, improvement or re-innovation.

Phase four, including the process of research, namely research-development works and the process of research result transformation to practical implementation, plays a significant role. The latter one determines the appearance of innovativeness. If we consider the scientific research result commercialization, the project research result should provide a particular offer for industry/business (Jasiński, 2009: 15).

A company is the key participant of an innovative process since, on the one hand it reports demand for new scientific-technical solutions, and on the other hand it offers supply of technical innovations. Nowadays, the acceleration of technical advance is not, contrary to all appearances, a scientist (a scientific institution) but an innovatively oriented entrepreneur (an innovative enterprise). An innovative company should be: based on knowledge, a learning institution, and a network. A. Sosnowska has undertaken a test of an innovative enterprise classification. She distinguishes two main types of such companies:

1) large international corporations, especially those acting in the areas of high technology;

2) small and medium enterprises acting in so called niche areas using market space not occupied by large corporation from different reasons. Small innovative companies are divided into three broad categories:

- small companies within traditional industry, e.g. textiles, footwear, woods, metal;

- modern small units applying so called market niche strategy in the industry of scientific instruments, electronics, computer assisted designing;

- small companies based on FONT (new technology based firms), those companies usually act in the areas described as technological clusters that appear in: biotechnology, energetic technology, advanced material technology and information technology (Jasiński, 2009: 26).

One of the characteristic feature in contemporary science and technology in the developed countries is appearance and development of companies based on new technology. The FONT type companies mean developing firms producing and selling goods and services that state a significant element of contemporary science. The basic feature that distinguishes such a company from other enterprises is conversion - science transfer (broadly defined) into a new technology (New technology-based firms in Britain and Germany, 1998: 2).

In the UK in 1980's there were over four hundred such companies near Cambridge. Such firms are set up by private entrepreneurs usually being hired among former workers of research-development departments (laboratories) of large industrial companies or university scientists or MA or PhD graduates. The characteristic features of the FONT type companies are: new on the market, small (employing on average dozen or several dozens of staff); based on venture capital, usually private one with a high risk rate; entitled to different financial preferences, independently from those which all small companies may use (Jasiński, 2009: 113).

\section{Innovative activity in the service sector in Poland and the EU}

Intelligent development based on knowledge and innovation that is one of the priorities of the Europe 2020 strategy demands strengthening innovativeness level both in production and service sectors. The highly 
developed countries experience proves that a significant element of their so far success is structural changes in economy and metamorphosis observed within the sector of services. A particular contribution into accelerating economy development belongs to services connected with creating and implementing innovativeness as well as generating and spreading information and other knowledge assets. The increase of service importance has become an economy rule and the demand of civilization advance in all countries regardless their advance level. The specific feature of the service sector is the growth of its importance together with the economy growth (Wiśniewska, 2011: 179).

There is a difference between innovativeness processes in industrial and service companies. The comparison of industrial and service innovations is presented in the Table 1 below.

Table 1. The comparison of the industrial and service innovations

\begin{tabular}{|l|l|}
\hline \multicolumn{1}{|c|}{ Industrial innovation } & \multicolumn{1}{c|}{ Service innovation } \\
\hline - Creation of new or improved products & - Creating new or improved services \\
- Introducing new or improved technology of production & - Introducing new or improved methods of services \\
- Implementing a new way of sale or purchase & - Applying a new way of interaction with customers and \\
- Opening a new market for sale of products & suppliers \\
- Applying new raw materials & - Opening a new market for services \\
- Implementing changes in the organization of production & - Applying new materials or instruments \\
& - Implementing changes in the organization of services \\
\hline
\end{tabular}

Source: Niedzielski, 2008: 232

Innovative activity in services means acquiring new technology while industry is a creator of new technological solutions. Those technologies derive from an independent development research. Service innovations are based mostly on knowledge acquired from outside. To present the difference between innovativeness of production and services it is claimed that patents for production sector is the same as trademarks for services. It means a bigger competitiveness in the sector of services since it is easier to appear on the market but more difficult to keep and last in the position of a leader (Gula, 2007: 18)

An important source in service innovations are employees, their creativity, enterprising and the level of knowledge including qualifications and competence. Thus, service activity is more focused on staff trainings in order to acquiring new knowledge. Statistics prove that the share of innovative companies grows together with the number of functioning entities both in industry and service sectors.

Among small companies in the service sector financial agency services are the most innovative ones. In the group of medium entities, innovations are most often implemented by IT companies, and among the so called large enterprises, the highest number belongs to mailing service and telecommunication. Both in industry and the service sector, actively innovative enterprises implement process innovations more often that product ones - see Table 2 .

Peculiar character of service activity causes the enterprises functioning in the sphere implement organizational or marketing innovations more often that product or process ones. The share of service companies which implemented that type of innovation in Poland and the EU-25 is presented in Table 3.

The decrease of the percentage of service companies implementing innovation in the total number of service enterprises in Poland in 2008 was also accompanied by the decrease (from $18.8 \%$ in 2006 to $12.6 \%$ in 2008 ) of the percentage of companies which had incurred expenditures on product and process innovations. Such a situation certainly influenced unfavorably the growth of the innovativeness level of the sector. The growth of expenditures for innovative activity by $51.8 \%$ should be evaluated positively, which was 12.6 billion zlotys in 2008 in the sector of services. The situation in the area is presented in Table 4. 
Table 2. Innovative enterprises in the sector of services and industry in Poland according to the kind of implemented innovations

\begin{tabular}{|c|c|c|c|c|}
\hline \multirow[b]{2}{*}{ Particulars } & \multicolumn{4}{|c|}{$\begin{array}{c}\text { Companies which implemented product and/or process innovations in } \\
\% \text { of all enterprises }\end{array}$} \\
\hline & Total & $\begin{array}{l}\text { New or significantly } \\
\text { improved products }\end{array}$ & $\begin{array}{c}\text { Including the } \\
\text { new ones for } \\
\text { the market }\end{array}$ & $\begin{array}{l}\text { New or significantly } \\
\text { improved processes }\end{array}$ \\
\hline \multicolumn{5}{|l|}{ Years 2004-2006 } \\
\hline Industry in total & 23.2 & 15.7 & 7.6 & 19.4 \\
\hline Services in total & 21.2 & 13.3 & 7.4 & 17.1 \\
\hline \multicolumn{5}{|l|}{ Years 2006-2008 } \\
\hline Industry in total & 21.3 & 15.5 & 9.3 & 17.0 \\
\hline Services in total & 15.6 & 10.3 & 6.3 & 12.3 \\
\hline $\begin{array}{l}\text { Bulk and commission trade } \\
\text { excluding car and motorbike trade }\end{array}$ & 12.7 & 7.4 & 5.0 & 9.1 \\
\hline Transport, tourist related activity & 10.3 & 5.7 & 1.9 & 8.9 \\
\hline Mail and telecommunication & 33.6 & 26.8 & 18.7 & 26.2 \\
\hline Financial brokerage & 39.3 & 33.1 & 15.9 & 31.3 \\
\hline IT & 34.1 & 29.7 & 24.7 & 26.4 \\
\hline $\begin{array}{l}\text { Activity concerning architecture } \\
\text { and engineering, research and } \\
\text { analysis }\end{array}$ & 16.2 & 10.0 & 7.4 & 12.4 \\
\hline
\end{tabular}

Source: Janasz, 2011: 190

Table 3. Organizational and marketing innovations in service enterprises in Poland and the EU-25

\begin{tabular}{|c|c|c|c|}
\hline \multirow{3}{*}{ Years } & \multicolumn{3}{|c|}{ Enterprises which implemented organizational and/or marketing innovations } \\
\hline & Total & $\begin{array}{c}\text { Organizational } \\
\text { innovations }\end{array}$ & Marketing innovations \\
\hline & \multicolumn{3}{|c|}{ in \% enterprises in total } \\
\hline \multicolumn{4}{|l|}{ UE-25 } \\
\hline $2002-2004$ & 26.0 & 23.7 & 13.0 \\
\hline \multicolumn{4}{|l|}{ POLAND } \\
\hline $2004-2006$ & 32.6 & 27.6 & 19.8 \\
\hline $2006-2008$ & 19.8 & 14.9 & 13.9 \\
\hline
\end{tabular}

Source: Janasz, 2011: 190

Table 4. The innovative activity expenditure structure changes in the sector of services in Poland

\begin{tabular}{|c|c|c|c|c|}
\hline \multirow{2}{*}{ Particulars } & \multicolumn{4}{|c|}{$\%$ expenses for innovative activity } \\
\hline & 1999 & 2003 & 2006 & 2008 \\
\hline Activity $\mathrm{B}+\mathrm{R}$ & 4.5 & 28.3 & 11.2 & 7.4 \\
\hline Purchase of ready technology (documents, rights) & 8.9 & 6.2 & 4.1 & 2.0 \\
\hline Software & 4.7 & 7.8 & 11.5 & 11.1 \\
\hline Innovative expenses for buildings and lands & 11.9 & 12.2 & 12.5 & 24.6 \\
\hline Investment expenses for machines and technical equipment & 62.3 & 37.8 & 47.3 & 48.7 \\
\hline Staff training & 2.4 & 1.7 & 1.3 & 0.6 \\
\hline Marketing & 3.3 & 2.5 & 4.9 & 2.9 \\
\hline Other & 2.0 & 3.5 & 7.2 & 2.7 \\
\hline
\end{tabular}

Source: Janasz, 2011: 191 
Table four above presents that the biggest percentage belongs to expenditure on machinery and technical machines in total expenditures on innovative activity in the service sector in Poland. Low and decreasing percentage of expenditures on research and development works since 2003 is alarming. This situation means prevailing egzogenic character of innovative changes. Well qualified employees are the basis of processes of generating innovations inside a company and it is also one of the key elements of building absorbent potential in case of implementing solutions acquired from outside. As the research undergone within CIS-4 proves that the lack of qualified staff is an important factor disturbing in running an innovative activity for $9.6 \%$ of the service sector companies of the EU-27. Therefore, constantly decreasing percentage of expenditures on staff trainings in the total expenditures on innovative activity in the service sector in Poland is worth taking into account.

\section{The innovation process and the regional development}

The regional innovative system consists of complementary and related sub-systems consisting of regional acting groups including:

- entites (production and service sub-system) participating in the system of creating innovation, technology transfer, implementing and commercialization of new solutions;

- scientific institutions and $\mathrm{B}+\mathrm{R}$ sector (educational and science and research sub-system) including different research and development companies, higher education and other scientific institutions acting in the area of innovation and technology transfer;

- innovativeness and technology transfer support institutions (infrastructural sub-system) created by numerous entities supporting innovative processes, e.g. technological parks, incubators, innovative technology transfer centers;

- local and regional authorities that are the connecting element and starting activity of particular systems through effective innovative policy described within regional innovation strategy.

Regional innovation system is a system of companies and public and private organizations that create innovation on the basis of interaction and common learning. The foundation of regional system innovation activity is social and cultural and institutional environment (Nowakowska, Przygodzki, Sokołowicz, 2011: 101).

Considering a company structure and external relations and innovation networks $\mathrm{PH}$. Cook indicated located interactive and worldwide innovation systems:

- Located - regional systems are dominated by small and medium enterprises sector. Culture and innovative skills of local companies are not properly developed but simultaneously local research units are open and capable of network cooperation with the companies functioning in the region. The public innovation sector and $\mathrm{B}+\mathrm{R}$ are of a significant importance, since the private sector is less significant. There are strong tendencies to create network and associations of different kinds between entities and public authorities.

- Interactive - in regional innovation systems their simultaneously exist large and small companies, in the system itself there is a "reasonable balance" between particular companies and their big complementary (entities of small and medium enterprises sector, large international corporations, $\mathrm{B}+\mathrm{R}$ units, public authorities).

- Worldwide - in regional innovation systems there is a dominance of global information supported by local sector of small and medium enterprises, (e.g. networks creating clusters), strongly dependant on the large international corporations. Innovation sources and research and development activity mostly derive from internal $\mathrm{B}+\mathrm{R}$ structures but simultaneously the systems mean well developed public infrastructure of innovation support, addressed to the sector of small and medium enterprises. In the sector private finances of innovation and research and development activity prevail. 


\section{Conclusions}

The analysis and comparison of the innovative activity in a balanced development of regions and organizations in Poland and the EU included in this derivation has been completed through discussing the following issues: an innovative process and innovativeness of organizations have been described, an innovative activity of the services sector in Poland and the EU has been proved as well as an innovative process and regional development have been compared. Through this analysis the following conclusions may be drawn:

- There are positive changes connected with innovations leading to facilitation of manufacturing processes.

- Knowledge management and constant progress in the technology and management areas is a necessary condition to the region and enterprise development.

- Observations and research indicate growing engagement of enterprise innovativeness, problems connected with their functioning in a given area including activity for local community.

- Development of the contemporary economy leads to the growth of the role and significance of knowledge, intellect, enterprising and enterprise innovativeness through employment innovativeness.

Drawing general conclusions, today's innovative activity and enterprising are thought to be a necessary condition to the economy and social growth and development thus it is the main topic of discussion of the Polish government and society as well as of other EU's countries. The expression of the above in the EU is so called Lisbon Strategy.

The research concerning the level of innovativeness in the EU has been undergone every year since 2000 within the European Innovation Scoreboard (EIS) project. EIS provides comparable results concerning the level of innovativeness in particular countries and shows the headway on the way to the most competitive economy in the world (according to the Lisobon strategy assumptions). It is also a European forum for comparison (benchmarking) and experience exchange between particular countries. The latest report International Institute for Management Development (IMD) evaluates competitiveness of 58 states according to 300 detailed criteria (World Competitiveness Yearbook, 2010). In the contemporary set of the most competitive world economies, Poland has noted, 2 years in a row, a big advance, from the $44^{\text {th }}$ up to the $22^{\text {nd }}$ place. Within the EU 27 Poland has overtaken 11 countries.

\section{References}

Dolińska, M. (2010). Innowacje w gospodarce opartej na wiedzy. Warszawa: Polskie Wydawnictwo Ekonomiczne S.A. Gula, K. (2007). Czy ktoś widziat innowacje w usługach. Innowacyjny start, Nr. 2 (5).

Janasz, W. (1999). Innowacyjne strategie rozwoju przemystu. Szczecin: Fundacja Uniwersytetu Szczecińskiego.

Janasz, W. (2011). Innowacje w zrównoważonym rozwoju. Warszawa: Difin.

Jasiński, A. H. (edit) (2009). Innowacje matych i średnich przedsiębiorstw w świetle badań empirycznych. Warszawa: Promocja XXI Sp. z o.o.

Lis, S., Szot-Gawryś, T. (2008). Przedsiębiorczość i innowacje-problem, koncepcje, wyzwania. Kielce: Wyższa Szkoła Umiejętności im. S. Staszica w Kielcach.

Matusiak, K. B. (2010). Budowa powiazań nauki z biznesem w gospodarce opartej na wiedzy. Rola i miejsce uniwersytetu $w$ procesach innowacyjnych. Warszawa.

New technology-based firms in Britain and Germany. Anglo-German Foundation. (1988). London.

Niedzielski, P. (2008). Zarzqdzanie innowacjami w przedsiębiorstwach ustugowych. In: B. Filipiak, A. Panasiak (eds.). Przedsiębiorstwo ustugowe. Zarzadzanie. Warszawa: PWN.

Nowakowska, A., Przygodzki, Z., Sokołowicz, M. E. (2011). Region w gospodarce opartej na wiedzy. Kapitał ludzkiInnowacje - Korporacje transnarodowe. Warszawa: Difin.

Pavitt, K et al. (1998). Managing innovation: Integrating technological, market and organizational change. Chichester: Wiley.

The World Competitiveness Scoreboard. (1988).

Wiśniewska, J. (2011). Aktywność innowacyjna sektora usług w Polsce. In: W. Janasz (ed.). Innowacje w zrównoważonym rozwoju organizacji. Warszawa: Difin. 


\section{INOVACINE VEIKLA DARNIAI PLETOJANT EUROPOS SĄJUNGS IR LENKIJOS REGIONUS BEI ORGANIZACIJAS}

SYLWIA ĆMIEL

Alcide De Gasperi Euroregionų ekonomikos universitetas Jozefow (Lenkija)

\section{Santrauka}

Šio straipsnio tikslas - išanalizuoti inovacinę veiklą darniai plètojant ES ir Lenkijos regionus bei organizacijas. Valstybė yra atsakinga už inovacijų lygi, finansų pervedimą tyrimams ir plètrai, tinkamų finansinių ir teisinių priemonių, skatinančių inovatyvią įmonių veiklą, taikymą, igyvendinant ekonominę politiką. Naujovių taikymas keliant ekonomiką yra pagrindinis Lenkijos ir ES vykdomos inovacinès politikos objektas. Organizacijos, ypač smulkios ir vidutinès, siekia bendradarbiauti inovacijų srityje su tos pačios šakos organizacijomis, kitomis šakomis toje pačioje šalyje, universitetais, verslą ir technologijas kuriančiomis $(\mathrm{V}+\mathrm{T})$ institucijomis, įskaitant laboratorijas, finansines inovacijas, mokslo ir technologijų parkus, vietos valdžios ir inovatyvios aplinkos atstovus. Čia minètinos ir konsultacinès bendrovės, mugių, parodų, konferenciju, seminarų ir mokymų organizatoriai. Lenkijoje inovatyvumas finansuojamas iš esmès pačių bendrovių ir jų tarpininkių, kurios padeda panaudoti ES fondų lèšas, taip pat finansinių arba kredito organizacijų, kurios teikia kapitalą (pvz., rizikos kapitalas).

PAGRINDINIAI ŽODŽIAI: inovacijos, vadyba, žiniu ekonomika.

JEL KODAI: O310 